Tony Gin MB ChB BSc FFARACS FFARCS, Gordon Yau MB BS FFARCS,

Kelvin Chan PhD FRPharmS FCP FIBIOL FACB, *

Michael A. Gregory MB BS FFARCS,

Teik E. Oh MB BS FFARACS FFARCS

\title{
Disposition of propofol infusions for Caesarean section
}

The disposition of propofol was studied in women undergoing elective Caesarean section. Indices of maternal recovery and neonatal assessment were correlated with venous concentrations of propofol. After induction of anaesthesia with propofol $2.0 \mathrm{mg} \cdot \mathrm{kg}^{-1}$, ten patients received propofol $6 \mathrm{mg} \cdot \mathrm{kg}^{-1} \cdot \mathrm{hr}^{-1}$ with nitrous oxide 50 per cent in oxygen (low group) and nine were given propofol $9 \mathrm{mg} \cdot \mathrm{kg}^{-1} \cdot \mathrm{hr}^{-1}$ with oxygen 100 per cent (high group). Pharmacokinetic variables were similar between the groups. The mean $\pm S D$ Vss $=2.38 \pm 1.16 \mathrm{~L} \cdot \mathrm{kg}^{-1} . \mathrm{Cl}=$ $39.2 \pm 9.75 \mathrm{ml} \cdot \mathrm{min}^{-1} \cdot \mathrm{kg}^{-1}$ and $t_{1} \beta=126 \pm 68.7 \mathrm{~min}$. At the time of delivery $(8-16 \mathrm{~min})$, the concentration of propofol ranged from $1.91-3.82 \mu \mathrm{g} \cdot \mathrm{ml}^{-1}$ in the maternal vein $(\mathrm{MV})$, $1.00-2.00 \mu \mathrm{g} \cdot \mathrm{ml}^{-1}$ in the umbilical vein (UV) and $0.53-1.66 \mu \mathrm{g}$. $\mathrm{ml}^{-1}$ in the umbilical artery (UA). Neonates with high UV concentrations of propofol at delivery had lower neurologic and adaptive capacity scores 15 minutes later. The concentrations of propofol were similar between groups during the infusion but they declined at a faster rate in the low group postoperatively. Maternal recovery times did not depend on the toral dose of propofol but the concentration of propofol at the time of eye opening was greater in the high group than the low group $\left(1.74 \pm 0.51\right.$ vs $\left.1.24 \pm 0.32 \mu \mathrm{g} \cdot \mathrm{ml}^{-1}, P<0.01\right)$. The rapid placental transfer of propofol during Caesarean section requires propofol infusions to be given cautiously, especially when induction to delivery times are long.

Nous avons mesuré l'élimination du propofol lors de césariennes électives et avons mis en relation le réveil maternel et la

\section{Key words}

ANAESTHESIA: obstetric, recovery; ANAESTHETICS, INTRAVENOUS: propofol; ANAESTHETIC TECHNIQUES: intravenous; PLACENTA: drug transfer.

From the Department of Anaesthesia and Intensive Care, Prince of Wales Hospital, The Chinese University of Hong Kong, Shatin, Hong Kong; and *Department of Pharmacology, The Chinese University of Hong Kong, Shatin, Hong Kong.

Address correspondence to: Dr. T. Gin, Department of Anaesthesia and Intensive Care, Prince of Wales Hospital, The Chinese University of Hong Kong, Shatin, Hong Kong. Accepted for publication 29,h August, 1990. performance du nouveau-né avec la concentration veineuse de propofol. Après une dose d'induction de $2.0 \mathrm{mg} \cdot \mathrm{kg}^{-1}$ de propofol, nous en perfusions $6 \mathrm{mg} \cdot \mathrm{kg}^{-1} \cdot \mathrm{ht}^{-1}$ de plus chez dix patientes qui respiraient 50 pour cent de protoryde d' azote avec de l'oxygène (groupe l) et $9 \mathrm{mg} \cdot \mathrm{kg}^{-1} \cdot \mathrm{h}^{-1}$ chez neuf respirant de l'oxygène pur (groupe 2). Les variables pharmacocinétiques étaient semblables dans les deux groupes avec un Vss de 2,38 $1,16 \mathrm{~L} \cdot \mathrm{kg}^{-1}$, une $\mathrm{Cl}$ de $39.2 \pm 9.75 \mathrm{ml} \cdot \mathrm{mn}^{-1} \mathrm{~kg}^{-1}$ et une $t_{\mathrm{g}} \beta$ de $126 \pm 68.7 \mathrm{mn}$. Au moment de la naissance $(8-16 \mathrm{~min}$ postinduction), les concentrations de propofol allaient de $1,91 \dot{a}$ $3,82 \mu \mathrm{g} \cdot \mathrm{ml}^{-1}$ dans le sang veineux maternel, de 1,00 à $2,00 \mu \mathrm{g}$. $\mathrm{ml}^{-1}$ dans la veine ombilicale es de $0,53 \dot{a} 1,66 \mu \mathrm{g} \cdot \mathrm{ml}^{-1}$ dans l'artère ombilicale. Les nouveaur-nés au sang veineur ombilical plus riche en propofol, avaient, 15 minutes après la nairsance. un "neurologic and adaptative capacity score" plus bas. Semblables pendant la période de perfusion, les concentrations de propofol diminuèrent plus vite chez le groupe 1 après l'opération. La dose totale de propofol n'influençait pas le réveil des patientes mais, à l'ouverture des yeux, celles du groupe 2 en avaient des concentrations plus élévées: $1,74 \pm$ 0,51 vs $1,24 \pm 0,32 \mu \mathrm{g} \cdot \mathrm{ml}^{-1}, \mathrm{P}<0,01$. A cause d' un transfert placentaire rapide, on doit perfuser le propofol avec prudence lors d'une césarienne surtout si l'intervalle entre l'induction et la naissance se prolonge.

Propofol is an intravenous anaesthetic agent which is suitable for use by infusion because it has a high total body clearance, short elimination half-life and rapid recovery characteristics. The desire for rapid maternal and neonatal recovery has led to the evaluation of infusions of propofol during Caesarean section. ${ }^{1,2}$

The pharmacokinetics of infusions of propofol have been studied previously ${ }^{3-5}$ but the rapid physiological changes at Caesarean section may alter the disposition of propofol and modify plasma concentrations of propofol. Previous studies showed that, after a bolus induction dose, total body clearance of propofol was increased at Caesarean section compared with non-pregnant patients ${ }^{6}$ and placental transfer was rapid. ${ }^{7}$ Infusions present a continuous and greater total dose of drug to the fetus so that higher concentrations of propofol and neonatal depression are possible. 
The aim of this study was to determine the pharmacokinetics of propofol infused at two different rates during Caesarean section, and use the data to provide a basis for interpreting maternal and neonatal recovery after anaesthesia. The clinical details of the patients in this study and their comparison with patients receiving a thiopentone/ nitrous oxide and enflurane technique have been reported previously. $^{2}$

\section{Methods}

The study was approved by the Research Ethics Committee of the Chinese University Faculty of Medicine and informed consent given by all patients. Nineteen Chinesc women of ASA physical status 1 undergoing elective Caesarean section after 37 weeks for a normal, singleton pregnancy were allocated randomly to a low-dose or high-dose infusion group. Electrolyte and liver function test results were normal and no patients were taking medications.

Ranitidine $150 \mathrm{mg}$ was given orally the night before and again two hours before surgery, while sodium citrate $0.3 \mathrm{M}, 30 \mathrm{ml}$, was administered 15 minutes before induction of anaesthesia. An intravenous catheter was inserted in the left forearm for drug and fluid administration while a long venous catheter was inserted in the other arm for blood sampling. Each patient was preoxygenated for three minutes. After a bolus of propofol $2.0 \mathrm{mg} \cdot \mathrm{kg}^{-1}$ over $20 \mathrm{sec}$, ten patients (low group) received propofol 6 $\mathrm{mg} \cdot \mathrm{kg}^{-1} \cdot \mathrm{hr}^{-1}$ and nitrous oxide 50 per cent in oxygen while nine (high group) received propofol $9 \mathrm{mg} \cdot \mathrm{kg}^{-1}$ $\mathrm{hr}^{-1}$ and oxygen 100 per cent. Succinylcholine, $1.5 \mathrm{mg} \cdot$ $\mathrm{kg}^{-1}$, was given to facilitate tracheal intubation, neuromuscular block was continued with atracurium $0.5 \mathrm{mg} \cdot \mathrm{kg}^{-1}$ and ventilation was controlled to maintain end-tidal carbon dioxide concentrations of 4.0 to 4.5 per cent (Normocap, Datex Ltd). After delivery of the neonate, an oxytocin infusion (20 units in $500 \mathrm{ml}$ five per cent glucose) was started and morphine $0.2 \mathrm{mg} \cdot \mathrm{kg}^{-1}$ was given IV. All neonates were assessed by one paediatrician who was unaware of the anaesthetic technique. Apgar scores at one and five minutes, and neurologic and adaptive capacity scores (NACS) at $15 \mathrm{~min}, 2$ and $24 \mathrm{hr}$ were recorded. All anaesthetic agents were discontinued at the last skin suture. Residual neuromuscular block was antagonised with neostigmine $2.5 \mathrm{mg}$ and atropine $1.2 \mathrm{mg}$.

Maternal blood samples were taken at $0,2.5,5,10$ and successive $15 \mathrm{~min}$ intervals during the infusion, at the time of delivery and at $0,2.5,5,10,20,30,60,120,240$, 360 and $480 \mathrm{~min}$ after the end of the infusion. At delivery, umbilical arterial and venous blood samples were taken for blood gas and propofol analysis. Blood was collected in lithium heparin tubes and stored at $4^{\circ} \mathrm{C}$.

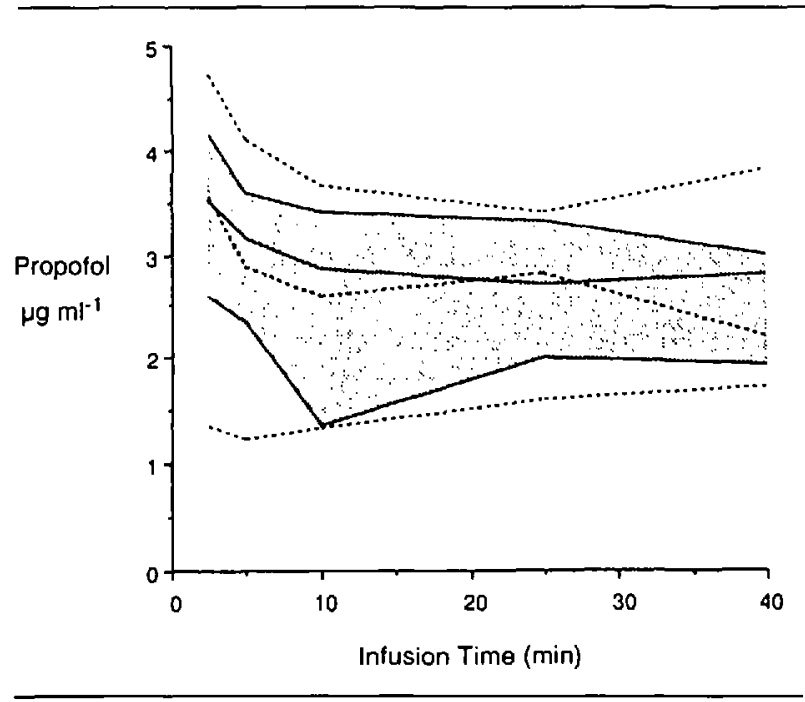

FIGURE I Median and range for maternal propofol concentrations after $2 \mathrm{mg} \cdot \mathrm{kg}^{-1}$ bolus and $6 \mathrm{mg} \cdot \mathrm{kg}^{-1} \cdot \mathrm{hr}^{-1}(\ldots \ldots)$ or $9 \mathrm{mg} \cdot \mathrm{kg}^{-1}$

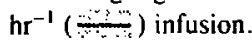

Maternal propofol concentrations were measured at four stages of recovery which corresponded to the times for eye opening, correct date of birth and after psychomotor testing at 25 and 60 min using a "postbox" test. ${ }^{8}$

The concentration of propofol in whole blood was determined by high-performance liquid chromatography and fluorescence detection as described previously. ${ }^{9}$ The blood concentration-time profiles of propofol were analyzed by a model independent method and pharmacokinetic variables calculated using standard formulae. ${ }^{10,11}$

Demographic data were compared using Student's t test. Pharmacokinetic variables and concentrations of propofol were compared using the Mann-Whitney test. Kendall Rank correlation was used to test associations between recovery times, anaesthetic duration, total propofol dose and concentrations of propofol. Statistical significance was accepted when $P \leq 0.05$.

\section{Results}

Demographic data were similar in both groups with age ranging from 21 to $37 \mathrm{yr}$, weight from 52 to $73 \mathrm{~kg}$ and height from 140 to $163 \mathrm{~cm}$. Initial sampling was incomplete from one patient in the high group and pharmacokinetic variables for this patient were not estimated. Anaesthetic time ranged between 31 and $68 \mathrm{~min}$.

The concentrations of propofol varied considerably among patients and the highest concentration (4.72 $\mu \mathrm{g} \cdot \mathrm{ml}^{-1}$ at $2.5 \mathrm{~min}$ ) was measured in a patient from the low infusion group. There were no differences in the concentrations of propofol during the infusion period between the two groups (Figure 1). At the end of the anaesthetic, maternal concentrations (mean $\pm \mathrm{SD}$ 


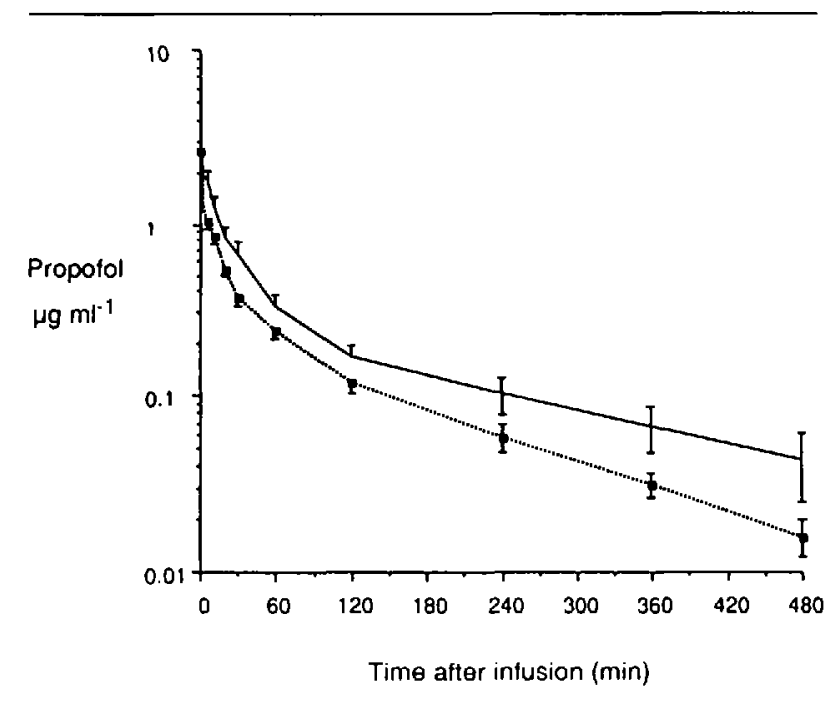

FIGURE 2 Decline in whole blood propofol concentration after stopping infusions at $6 \mathrm{mg} \cdot \mathrm{kg}^{-1} \cdot \mathrm{hr}^{-1}(\ldots \ldots)$ or $9 \mathrm{mg} \cdot \mathrm{kg}^{-1} \cdot \mathrm{hr}^{-1}$ $(-)$.

(range)) were similar between groups (high: $2.60 \pm 0.36$ $(1.95-3.01) \mathrm{mg} \cdot \mathrm{ml}^{-1}$ and low: $2.55 \pm 0.73(1.73-3.82)$ $\mathrm{mg} \cdot \mathrm{ml}^{-1}$ ) despite the high-infusion group receiving 38 per cent more drug overall. After the infusion was stopped, the concentration of propofol declined at a faster rate in the low group and was less from 2.5 to $30 \mathrm{~min}$ compared with the high group $(P<0.05)$ (Figure 2$)$.

There were no differences detected between the two groups in total body clearance $(\mathrm{Cl})$, apparent volume of distribution at steady state (Vss) or elimination half life $\left(\mathrm{t}_{2} \beta\right)$ (Table I). Although mean $\mathrm{Cl}$ was nearly identical, mean Vss and $T_{2} \beta$ were approximately 50 per cent larger in the high group compared with the low group. Pharmacokinetic variables did not vary with duration of infusion time.

Induction to delivery (I-D) times ranged from eight to 16 minutes and there was insufficient blood for analysis from two umbilical arteries (UA) in the low infusion group and one UA in the high group. The maternal venous

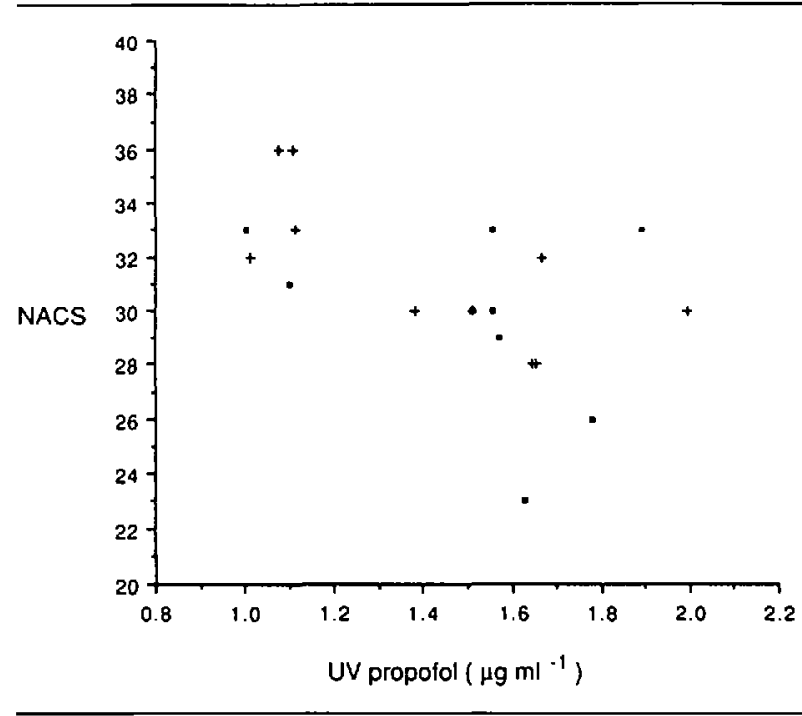

FIGURE 3 Umbilical venous propofol concentration at delivery vs neurological and adaptive capacity scores $15 \mathrm{~min}$ later. Negative Kendall Rank Correlation $(P<0.05) .(+=$ low-infusion group, $\cdot=$ high-infusion group)

(MV) concentration of propofol was always higher than the umbilical venous (UV) concentration (Table II). The two groups of neonates were pooled because there were no differences in their demographic data, I-D times or the maternal and umbilical concentrations of propofol at delivery. There was no correlation between I-D time and Apgar scores, NACS or the ratios UV/MV and UAVUV. Apgar scores and NACS did not correlate with UA or UV concentrations of propofol except for the NACS at 15 minutes which were lower when the UV concentrations were high (Figure $3, P=0.01$ ). Neonates with low NACS or Apgar scores did not have other obvious precipitating factors such as prolonged delivery time, low birth weight or maternal hypotension.

Recovery times were not correlated to total propofol dose or anaesthetic time (Table III). There was no difference between groups in the time to open eyes despite higher concentrations of propofol in the high group $(P<$ 0.05 ). After eye opening, patients in the high infusion

TABLE I Pharmacokinetic variables: area under time concentration curve from zero time to infinity $\left(A \cup C^{\infty}\right)$, total body clearance $(\mathrm{Cl})$, apparent volume of distribution at steady slate (Vss) and climination half life $\left(t_{i} \beta\right)$

\begin{tabular}{|c|c|c|c|c|c|c|}
\hline & \multicolumn{2}{|c|}{ High infusion } & \multicolumn{2}{|c|}{ Low infusion } & \multicolumn{2}{|l|}{ Total } \\
\hline & Mean & $95 \% \mathrm{Cl}$ & Mean & $95 \% \mathrm{Cl}$ & Mean & $95 \% \mathrm{CI}$ \\
\hline $\operatorname{AUC}^{\infty}\left(\mu \mathrm{g} \cdot \min \cdot \mathrm{ml}^{-1}\right)$ & 224 & $153-294$ & 173 & $140-206$ & & \\
\hline $\mathrm{Cl}\left(\mathrm{ml} \cdot \min ^{-1} \cdot \mathrm{kg}^{-1}\right)$ & 40.8 & $32.3-49.2$ & 38.0 & $31.0-45.0$ & 39.2 & $34.4-44.1$ \\
\hline Vss $\left(L \cdot \mathrm{kg}^{-1}\right)$ & 3.08 & $1.92-4.24$ & 1.82 & $1.45-2.19$ & & \\
\hline$t_{3} \beta(\min )$ & 151 & $71.8-230$ & 107 & $83.9-130$ & & \\
\hline
\end{tabular}




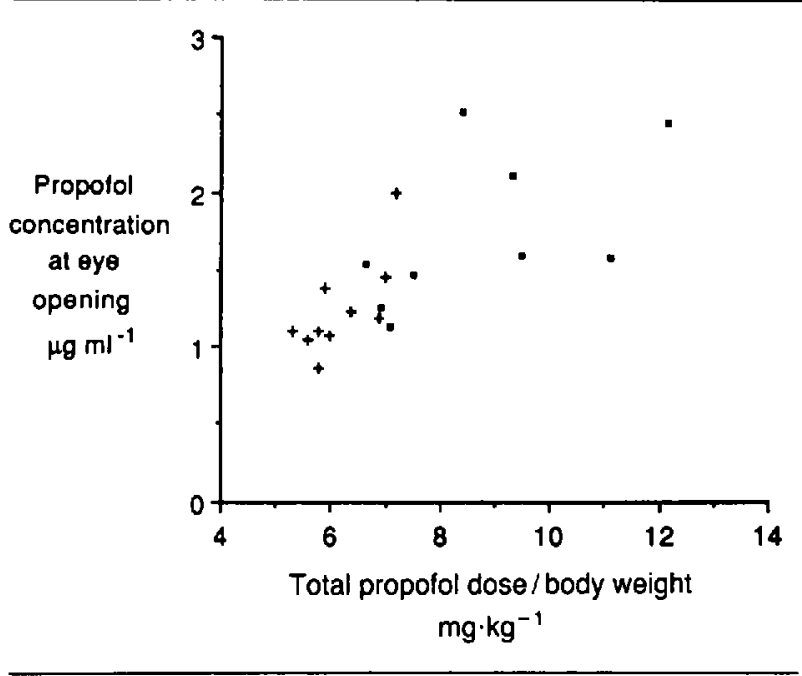

FIGURE 4 Venous propofol concentration at time of eye opening vs total propofol dose/body weight. Positive Kendall Rank correlation $(P<0.05)$. ( $+=$ low-infusion group, ${ }^{\bullet}=$ high-infusion group $)$.

group took longer than those in the low group to give their correct date of birth $(P<0.05)$ but concentrations of propofol at this time were not significantly different. However, in both groups, higher total doses of propofol correlated with higher concentrations of propofol at the times of eye opening and date of birth $(P<0.05)$ (Figure 4). Post box performance was similar between groups at both 25 and $60 \mathrm{~min}$.
There were no anaesthetic or obstetrical complications and no patient admitted to awareness or dreaming during the procedure.

\section{Discussion}

There was a large individual variation in the pharmacokinetic variables at both infusion rates but the mean total body clearance of propofol was almost identical between groups. High UV propofol concentrations were associated with low NACS scores and recovery was marginally slower in the high infusion group. However, the observed differences were clinically unimportant.

Nitrous oxide was used in the low group as part of an overall anaesthetic technique to compensate for the lower infusion rate of propofol but this should not alter the kinetics of propofol significantly.

A previous study showed that steady-state blood concentrations of propofol were linearly related to infusion rates of 3,6 and $9 \mathrm{mg} \cdot \mathrm{kg}^{-1} \cdot \mathrm{hr}^{-1}$ with infusion times of at least two hours and patients receiving the $9 \mathrm{mg} \cdot \mathrm{kg}^{-1}$. $\mathrm{hr}^{-1}$ infusion rate tended to have a smaller Vss and shorter ${ }_{4} \beta .^{3}$ In this study, concentrations of propofol were similar between the two groups because a loading dose was used and the infusion times were too short to reach steady state. The high group tended to have a higher Vss and longer $t_{i} \beta$ and this finding agrees with a more recent report. ${ }^{5}$ The high-infusion group should have greater tissue stores of propofol and the longer $4 \beta$ is caused by

TABLE II Propofol concentration data from maternal vein (MV), umbilical vein (UV) and umbilical artery (UA) at time of delivery

\begin{tabular}{|c|c|c|c|c|c|c|c|}
\hline & \multicolumn{3}{|c|}{ High infusion } & \multicolumn{3}{|c|}{ Low infusion } & \multirow{2}{*}{$\begin{array}{l}\text { Total } \\
95 \% \mathrm{Cl}\end{array}$} \\
\hline & Mean & $S D$ & Range & Mean & $S D$ & Range & \\
\hline$M V\left(\mu g \cdot m l^{-1}\right)$ & 2.80 & 0.43 & $(2.30-3.58)$ & 2.90 & 0.65 & $(1.91-3.82)$ & \\
\hline $\mathrm{UV}\left(\mu \mathrm{g} \cdot \mathrm{ml}^{-1}\right)$ & 1.51 & 0.29 & $(1.00-1.90)$ & 1.42 & 0.33 & $(1.01-2.00)$ & \\
\hline $\mathrm{UA}\left(\mu \mathrm{g} \cdot \mathrm{ml}^{-1}\right)$ & 0.90 & 0.18 & $(0.56-1.06)$ & 0.93 & 0.39 & $(0.53-1.66)$ & \\
\hline UV/MV & 0.54 & 0.14 & $(0.36-0.78)$ & 0.50 & 0.13 & $(0.33-0.79)$ & $0.46-0.59(n=18)$ \\
\hline UA/UV & 0.57 & 0.08 & $(0.50-0.68)$ & 0.64 & 0.17 & $(0.35-0.85)$ & $0.54-0.68(n=16)$ \\
\hline
\end{tabular}

TABLE IIl Blood propofol concentrations during maternal recovery. ${ }^{*} P<0.01$

\begin{tabular}{|c|c|c|c|c|c|c|}
\hline & \multicolumn{3}{|c|}{ High infusion } & \multicolumn{3}{|c|}{ Low infusion } \\
\hline & Mean & $S D$ & Range & Mean & $S D$ & Range \\
\hline Eye opening (min) & 6.0 & 1.9 & & 6.0 & 1.6 & \\
\hline propofol $\left(\mu \mathrm{g} \cdot \mathrm{ml}^{-1}\right)^{*}$ & 1.74 & 0.51 & {$[1.13-2.52]$} & 1.24 & 0.32 & [0.86-1.99] \\
\hline Date of birth (min) & 11.6 & 3.4 & & 9.0 & 1.9 & \\
\hline propofol $\left(\mu \mathrm{g} \cdot \mathrm{ml}^{-1}\right)$ & 1.24 & 0.45 & {$[0.83-2.06]$} & 1.01 & 0.32 & {$[0.58-1.56]$} \\
\hline Postbox $60 \mathrm{~min}$ (\% control) & 0.84 & 0.27 & & 0.80 & 0.21 & \\
\hline propofol $60 \mathrm{~min}\left(\mu \mathrm{g} \cdot \mathrm{ml}^{-1}\right)$ & 0.33 & 0.14 & {$[0.16-0.61]$} & 0.24 & 0.08 & {$[0.14-0.37]$} \\
\hline
\end{tabular}


the slow return of propofol from the deep compartment. The contribution of the area under the concentration-time curve from $480 \mathrm{~min}$ to infinity to the total area from zero time to infinity was larger in the high-infusion group (6.6 per cent) than in the low-infusion group ( 1.5 per cent). The different anaesthetic techniques between studies and also within this study make further interpretation difficult. Mean Vss and $\mathrm{t}_{\mathrm{B}} \beta$ values in this study were similar to those obtained in other non-pregnant patients who received opioid drugs and muscle relaxants for surgery ${ }^{4}$ but the large standard deviations generate uncertainty as to the true values. During pregnancy, changes in Vss affect calculations of $t_{2} \beta$ so that this is a less reliable index of the rate of metabolism and clearance is a more meaningful indicator. $^{12}$

There was no difference in clearance between the two infusion rates and this would imply that elimination was not affected by saturation kinetics. Total body clearance in this study was greater than that calculated in nonpregnant patients after infusions of propofol. ${ }^{3-5}$ This observation has also been reported after bolus induction doses of propofol. ${ }^{6}$ A comparison among patients for Caesarean section, postpartum sterilization and nonpregnant laparoscopic sterilization suggests that the physiological changes of pregnancy are responsible for the increased clearance of propofol more than the loss of blood and placental and fetal tissues at operation (unpublished observations).

It is difficult to make inferences about UV/MV or UA/UV with respect to I-D time as serial samples were not taken in the same mother and fetus. The mean UV/MV ratio of 0.52 is lower than the $0.65-0.85$ seen after bolus induction doses of propofol $\mathrm{I}^{1,7,13.14}$ and the 0.76 during an infusion study with I-D times of 7-31 min. ${ }^{1}$ Our I-D times $(8-16 \mathrm{~min})$ are shorter than the previous infusion study and the lower UV/MV would indicate there is still a gradient for placental transfer from the maternal to fetal circulations. The mean UAVUV ratio of 0.61 is similar to the 0.70 with previous infusions ' and 0.67 after bolus induction with short I-D times of $4-7$ min. ${ }^{17}$ This indicates continuing fetal tissue uptake. However, bolus induction studies with longer I-D times have UAVUV ratios of 1.09 and 1.07 which imply more complete fetal distribution. ${ }^{1,7}$

Neonatal depression in the low-infusion group was similar to that found after an anaesthetic technique using thiopentone for induction of anaesthesia and nitrous oxide and enflurane for maintenance of anaesthesia. ${ }^{2}$ The negative correlation between NACS and UV concentrations of propofol provides some evidence of neonatal depression due to propofol. Although infusion times were too short to differentiate maternal concentrations of propofol between the two groups, a high-dose infusion combined with a long induction to delivery time is likely to produce high UV concentrations of propofol and low neonatal NACS scores. The neonatal elimination of propofol is slower than the maternal elimination (unpublished observations). Neonatal glucuronidation is poorly developed but sulphation activity is similar to that found in adults. ${ }^{15}$

Concentrations of propofol at delivery were higher than those at the time of eye opening in both groups. However, one patient in the high infusion group had a concentration before delivery, at ten minutes $\left(1.36 \mu \mathrm{g} \cdot \mathrm{ml}^{-1}\right)$, which was lower than the concentration at eye opening $(2.45$ $\mu \mathrm{g} \cdot \mathrm{ml}^{-1}$ ). She did not experience awareness but this disconcerting result suggests that awareness is possible when propofol alone is used.

The speed of patient recovery is determined by the rapid decline in the concentration of propofol rather than the total dose administered and concentrations of propofol at the end of the infusion were similar between groups. However, the concentration of propofol declined at a slower rate in the high group after stopping the infusion and this is probably a result of greater tissue stores of propofol in the high group. Acute tolerance to propofol may occur as patients receiving higher dose infusions tend to recover at higher blood concentrations than patients receiving lower dose infusions ${ }^{5}$ and this was also apparent in this study. Eye opening times were similar between groups but initial recovery in the low-infusion group may have been delayed by the residual effects of nitrous oxide. Although concentrations of propofol were low during psychomotor testing, most patients did not return to their baseline scores. It is likely that postoperative pain and side effects of other medications, such as opioid drugs, would preclude full recovery.

With the anaesthetic times in this study, the lowinfusion group had similar propofol concentrations and produced clinically preferable anaesthetic conditions compared with the high-infusion group. ${ }^{2}$ Placental transfer of propofol was rapid and high-dose infusion regimes with long induction to delivery times would appear to be undesirable.

\section{Acknowledgement}

We would like to thank ICI Pharmaceuticals for their support.

\section{References}

1 Dailland P, Cockshott ID, Lirzin JD et al. Intravenous propofol during Cesarean section: placental transfer, concentrations in breast milk and neonatal effects. A preliminary study. Anesthesiology 1989; 71: 827-34. 
2 Gregory MA, Gin $T$, Yau G, Leung $R K W$, Chan $K$, Oh $T E$. Propofol infusion anaesthesia for Caesarean section. Can J Anacsth 1990; 37: 514-520.

3 Gepts E. Camu F. Cockshott ID, Douglas EJ. Disposition of propofol administered as constant rate intravenous infusions in humans. Anesth Analg 1987; 66: 1256-63.

4 Shafer A, Doze VA, Shafer SL, White PF. Pharmacokinetics and pharmacodynamics of propofol infusions during general ancsthesia. Anesthesiology 1988; 69: 348-56.

5 Cockshott ID, Douglas EJ, Prys-Roberts C, Turtle $M$. Coates $D P$. The pharmacokinetics of propofol during and after intravenous infusion in man. Eur $J$ Anaesthesiol 1990; 7: 265-76.

6 Gin T, Gregory MA, Buckley T, Chan K, Oh TE. The pharmacokinetics of propofol in women undergoing clective caesarean section. Br J Anaesth 1990; 64: 148-53.

7 Gin T, Gregory MA, Chan K, Oh TE. Maternal and fetal levels of propofol at Caesarean section. Anaesth Intensive Care 1990; 18: 180-4.

8 Craig J, Cooper GM, Sear JW. Recovery from day-case anaesthesia. Comparison between methohexitone, althesin and etomidate. Br J Anaesth 1982; 54: 447-51.

9 Chan $K$, Gin $T$. Liquid chromatographic assay for propofol, a new i.v. anaesthetic, in maternal and umbilical blood samples. Neurosci Lett [Suppl] 1990; 37: S23.

10 Gibaldi $M$, Perrier $D$. Non compartmental analysis based on statistical moment theory. In: Swarbrick J (Ed.). Drugs and the Pharmaceutical Sciences, Vol 15. New York: Marcel Dekker, 1982: 409-17.

11 Perrier D, Mayersohn $M$. Noncompartmental determination of the stcady-state volume of distribution for any mode of administration. J Pharm Sci 1982; 71: 372-3.

12 Perucca E. Drug metabolism in pregnancy, infancy and childhood. Pharmacol Ther 1987; 34: 129-43.

13 Moore J, Bill KM, Flynn RJ, McKeating KT, Howard $P J$. A comparison between propofol and thiopentone as induction agents in obstetric anaesthesia. Anaesthesia 1989; 44: 753-7.

14 Valtonen $M$, Kanto $J$, Rosenberg $P$. Comparison of propofol and thiopentone for induction of anaesthesia for elective Caesarean section. Anaesthesia 1989; 44: 758-62.

15 Besunder JB, Reed MD, Blumer JL. Principles of drug biodisposition in the neonate. A clinical cvaluation of the pharmacokinetic-pharmacodynamic interface (Part I). Clin Pharmacokinet 1988; 14: 189-216. 